\title{
Worm-lobopodian assemblages from the early Cambrian Chengjiang biota: insight into the "pre-arthropodan ecology"?
}

\author{
Jean Vannier*, Emmanuel L. O. Martin
}

Univ Lyon, Université Lyon 1, ENS de Lyon, CNRS, UMR 5276 LGL-TPE, Bâtiment GEODE, 2, rue Raphaël Dubois, 69622 Villeurbanne, France.

Correspondence and requests should be addressed to J.V. (jean.vannier@univ-lyon1.fr)

\begin{abstract}
Well-preserved assemblages dominated by scalidophoran worms (Cricocosmia, Mafangscolex) and lobopodians (Paucipodia, Microdictyon, Onychodictyon and undetermined xenusiid) are described from the Early Cambrian Chengjiang biota of China. This fossil material provides the opportunity to reassess key aspects of the functional morphology and lifestyles of the two groups. Both lobopodians exemplified here by Paucipodia and worms relied on a hydrostatic skeleton for support and locomotion and have direct functional analogues in extant onychophorans and priapulids, respectively. Retractorlike muscles attached to terminal claws probably assisted leg elevation in the lobopodians. Whereas lobopodians were essentially walkers and climbers, Cricocosmia and Mafangscolex were most likely subhorizontal burrowers. Their external ornament (phosphatic circular microplates or spiny sclerites) is interpreted as a possible adaptation for tunnelling close to the water-sediment interface. These assemblages seem to represent in-situ faunal associations and suggest that lobopodians and worms might have shared the same habitat and possibly exploited the same detrital food source. However, no evidence indicates that they interacted in predator-prey relationships. Finally, we hypothesize that during a time interval preceding Cambrian Stage 2, scalidophoran worms and lobopodians were the prevalent ecdysozoan component of early animal communities, and introduce the notion of a possible "pre-arthropodan ecology".
\end{abstract}

Keywords: Cambrian, Lobopodians, Ecdysozoa, Scalidophora, Palaeoscolecida, Chengjiang biota

\section{Introduction}

The faunal composition of Cambrian exceptional biotas clearly highlights that, soon after the great animal diversification started, arthropods became a major animal element of marine communities in terms of species diversity, disparity and numerical abundance. They rapidly evolved into a wide range of morphologies and complex ecologies and started to play a pivotal role in marine trophic webs (e.g., Dunne et al., 2008; Vannier, 2012, Vinther et al., 2014; Zacaï et al., 2016). An increasing amount of fossil and molecular evidence suggests that euarthropods most likely evolved from soft-bodied ecdysozoans, presumably cycloneuralian worms via lobopodians, a paraphyletic group of non-articulated animals (Liu and Dunlop, 2014) resembling modern Onychophora (e.g., Telford et al., 2008; Dunn et al., 
2008; Edgecombe, 2009; Daley et al., 2009; Legg et al., 2012; Ou et al. 2012; Smith and Ortega-Hernandez, 2014; Smith and Caron, 2015). Unless we assume that all ecdysozoan groups appeared at the same time, it is conceivable that, before euarthropods flourished and established their supremacy, the benthic marine ecosystem was once occupied by a variety of non-articulated ecdysozoans.

Well-preserved fossil assemblages of lobopodians and ecdysozoan (scalidophoran) worms are described here from the early Cambrian Chengjiang exceptional biota (Yunnan Province, China; ca $520 \mathrm{Ma}$; Hou et al., 2004). We analyse their composition and also important aspects of the functional morphology and possible lifestyles of both animal groups. Lobopodian ecology has rarely been studied in details, mainly because of the lack of comparative data from extant analogues (Chen et al., 1995; Budd, 2001; Liu et al., 2008; Vannier et al., 2014). However, several recent papers have suggested the onychophorans as possible remote lobpodian ancestors and as a potential resource for understanding key aspects of lobopodian morphology and lifestyles (Smith and Ortega-Hernandez, 2014; Smith and Caron, 2015). Interpreting the functional morphology and ecology of early ecdysozoan worms may appear in some way easier because worms with a comparable body plan can be readily observed in present-day marine environments (e.g., priapulids; Huang, 2005; Vannier et al., 2010). However, such palaeoecological interpretations concerning their palaeoecology must be cautiously conducted. The infaunal lifestyles of Cambrian scalidophoran worms have been recently challenged (Huang et al., 2014) warranting reanalysis of their behaviour and interaction with the sediment. Here we critically review scalidophoran worm and lobopodian ecology in light of interpretations proposed by previous authors and our own observations.

\section{Material and methods}

The fossil material studied here (Supp. Table 1) comes from the Maotianshan Shale Member of the Yu'anshan Formation (Lower Cambrian, Series 2, Stage 3) and was collected from Jianshan (JS) and Mafang (MF), both near the small town of Haikou near Chengjiang (ca $40 \mathrm{~km}$ SE of Kunming, Yunnan Province, China; see locality map in Hu, 2005, fig. 1). It consists of rock slabs exposing well-preserved aggregations of worms associated with other faunal elements such as lobopodians. This material is stored in the collections of the Early Life Institute (ELI numbers), Northwest University and the Northwest University Museum (XDB numbers). Specimens were observed under a Leica MZ125 stereomicroscope microscope equipped with Plan 1.0x and Planapo 1.6x lenses, a digital camera and Leica LAS 3.7.0 imaging system with multifocus option, and were photographed using a D3X-Nikon camera with Nikon Micro-Nikkor $60 \mathrm{~mm}$ lens. Scanning electron microscopy (FEI Quanta FEG 250) and Energy dispersive X-ray spectroscopy (EDX) analysis were used (CT $\mu$ facilities at the University Lyon 1) to study the detailed morphology of the faunal elements and their chemical composition. Images were acquired with Secondary Electron (SE) and BackScattered Electron (BSE) detectors operating at $15 \mathrm{KV}$, under high vacuum. Fossil specimens (Ayshaeia, Hallucigenia) from the collections of the Smithsonian National Museum of Natural History (USNM, Washington D.C., USA) and the Museum of Comparative Zoology (MCZ, Yale University, Cambridge, Mass., USA) were used for comparative studies. Biological material (priapulid worms) was collected from the Gullmar fjord near the Sven Lovén Centre for Marine Sciences at Kristineberg, Sweden and from the surroundings of the Nikolai Pertsov White Sea Biological Station, Russia. 


\section{Composition of lobopodian-worm assemblages}

We describe here aggregations of worms covering the surface of individual bedding planes from the early Cambrian Maotianshan Shale, which are associated with lobopodians (Figs 1, 2) and a few other faunal elements. These fossil assemblages (worm-lobopodian assemblages abbreviated as WLA) are largely dominated by Cricocosmia jinningensis (Hou and Sun, 1988; Huang, 2002; Han et al., 2007; Huang et al., 2014) which accounts for more than $95 \%$ of the total number of worm individuals (Fig. 3). The remaining $5 \%$ is represented by Mafangscolex sinensis (Hou and Sun, 1988; Huang, 2005; Huang et al., 2014) (Fig. 4). These two species can be easily distinguished from one another by their external ornament. Mafangscolex sinensis is a typical palaeoscolecid worm with a dense cuticular ornament made of primarily phosphatic circular platelets (Fig. 4c-e) and very narrow body annulations. The trunk of Cricocosmia jinningensis bears a double row of sclerites (Fig $3 \mathrm{f}-\mathrm{h}$ ) which have a circular basis, a short conical projection and a very fine tuberculate micro-ornament (Han et al., 2007). Each annulus bears one pair of sclerite. In contrast with Mafangscolex, EDX analysis indicates that the Cricocosmia sclerites contain no phosphate. Cricocosmia jinningensis is characterized by a relatively long, cylindrical pharynx armed with numerous tiny teeth and a ring of spines and hooks around the distal part of the proboscis (Fig. 1d). These features are noticeably less well preserved in WLA specimens (Fig. 3d; Han et al., 2007). Both Cricocosmia jinningensis and Mafangscolex sinensis are primarily represented by mostly subadult and adult forms, with some juveniles (Fig. 3a, b). Their most frequent faunal associates are lobopodians, especially Paucipodia haikouensis (Luo et al., 1999; Liu et al., 2013). This species has a relatively simple external morphology characterized by a long cylindrical body with largely spaced slender, finely annulated legs (9 pairs; Liu and Dunlop, 2013) terminated by at least one claw (Fig. 5b, c, e). The internal anatomy of Paucipodia haikouensis shows a cylindrical gut surrounded by undetermined but well-delimited, possibly connective tissues that clearly extend into each leg and are attached to the basis of the claw (Fig. 5a, b; Suppl. Fig. 1). These presumed connective tissues may include muscle fibers and tendon-like structures that may have been capable of withstanding tension during the locomotion process. The interspace between these possible connective tissues and the thin outer cuticle is relatively colourless and probably corresponds to the coelomic cavity of the animal (Fig. 5b, d). Small cup-like possibly ectoparasitic organisms (Jian Han, personal communication to JV) seem to be attached the leg cuticle of Paucipodia haikouensis (Fig. 5a, b). Microdictyon sinicum (Chen et al., 1989, 1995; Hou and Bergström, 1995; Zhang and Aldridge, 2007; Liu and Dunlop, 2013) and Onychodictyon ferox (Hou et al., 1991; Liu et al., 2008; Ou et al., 2012) also occur in WLA (Figs 1, 2). In contrast with Paucipodia, these lobopodians had a conspicuous series of strong dorsal sclerites adjacent to each pair of legs. One specimen of Onychodictyon ferox (Fig. 5j) exhibits strong claws and a possible funnelshaped pharynx (Fig. 5j). A much larger lobopodian is exposed on the surface of one rock slab (Fig 1a, b) but lies about $2 \mathrm{~mm}$ below the layer where the worms are concentrated. Its anterior part bears stout conical legs and a pair of frontal, curved appendages armed with claws (Fig. 5l-o). This unnamed xenusiid lobopodian had well-developed digestive glands (Vannier et al., 2014) and a broad mouth opening that probably housed a funnel-shaped pharynx (Fig 5I). This xenusiid may have reached $20 \mathrm{~cm}$ in length whereas the other WLA lopobodians had a smaller size. Phlogites longus (Luo et al., 1999, Chen et al., 2003; Chen, 2004, 2009; Hou et al., 2006; Caron et al., 2010) is represented in WLA by several specimens 
(Figs 1c, e; 2e, f; 6a) characterized by a long flexible stolon and a calyx-like body filled with a spacious stomacal pouch. Phlogites was recently interpreted as a tentaculate, sessile primitive deutorostome (Caron et al., 2010). Other observed sessile organisms included rare inarticulate undetermined brachiopods (Fig. 6b). Arthropods are virtually absent from WLA except for one naraoiid juvenile (Fig. 6c) and rare undertermined cuticular fragments. Bradoriids which often abound in the Chengjiang faunal assemblages do not occur here. One slab displays a small patch crowded with small shelly fossils, among them tiny hyolithid conical shells (Fig. 1a, b). Entangled filaments of probable algal origin such as Sinocylindra yunnanensis (Chen and Erdtmann, 1991; Steiner et al., 2005; Hu, 2005) (Fig 6D) are rather frequent in WLA and add to other dark-coloured undetermined fragments of possible organic origin.

\section{Preservation and taphonomy}

The worms and associated organisms do not appear as isolated elements on the rock surface but slightly overlap each other (Figs 1,2 ) to form a generally dense spatial concentration. These elements are strongly compressed, lie parallel to bedding and are preserved within a very thin layer that never exceeds $1 \mathrm{~mm}$. No preferential orientation can be seen in WPA thus contrasting with accumulation patches or pockets that typically consists of heterogeneous and reworked skeletal elements. Complete worms are rare and their anterior part is almost always missing. Numerous worm fragments are curved and often appear as loops (Fig. 3B). The trunk fragments of Cricocosmia jinningensis neither show sharp cuticular outines nor strongly defined boundaries between annuli. When preserved, the everted pharynx appears as a blurry feature having lost most of its original shape (Fig 1d). Although sclerites are still visible, most of their original three-dimensional relief is missing (compare Fig. 3c, h). Comparisons with complete and best-preserved specimens (e.g., Fig. 3d, e) suggest that worms from WLA have undergone pre-and/or-postburial decay. The effect of pre-and/or-post burial decomposition is less marked in Mafangscolex sinensis which usually displays sharper trunk outlines. Its closely packed mineralized microornament might have helped maintain the coherence of underlying tissues after death. The gut tract of most worms is typically preserved as fragmented carbonaceous films (Fig 3a; EDX, Fig. 7) which most likely represent the remnants of organic-rich gut contents of unknown origin. Although rarely complete and always compressed WLA lobopodians are well-preserved. No major physical distortion has altered the original cylindrical or conical shape of their body features (e.g., trunk and legs). Dorsal sclerites are still attached to their underlying soft tissues (e.g., Onychodictyon, Microdictyon; Figs 5f, 6a) and some assumed connective tissues are remarkably well-preserved (e.g., Paucipodia; Fig. 5b-d). The preservation mode of WPA fossils is comparable with that of other Chengjiang fossils and Burgess Shale-type fossils in general (Gaines et al., 2012). They are primarily preserved as carbonaceous compression films replicated by clay minerals. Scanning Electron Microscopy (SEM) and EDX analysis (WLA; Fig. 7) confirm that a very thin aluminosilicate film made of small (ca. $2 \mu \mathrm{m}$ ) horizontally imbricated clay minerals, covers the external surface of the worms (Fig. 7k-m). These minerals contrast with those of the surrrounding matrix, which are coarser and randomly distributed. Small iron oxide aggregates and isolated spherules are abundant in the worms and other WLA fossils, giving them their typical reddish colour. These oxides are pseudomorphs of originally framboid pyrite (Fig. 7h, i) which is a common by-product of sulphate-reducing bacterial oxidation of the original organic compounds of animal remains 
(Gabbott, 2004). Palaeoscolecidan worm from the lower Ordovician Fezouata Shale have a very similar mode of preservation (Martin et al., 2016a, $b$ in press). Carbon is present within the worms body, though with much higher concentrations in the gut (Figs 3a-c, 4a, 7e-g). Phosphorus occurs exclusively within the palaeoscolecid platelets (Fig. 4c-e, Suppl. Fig. 2). Polished transverse sections through WLA (Fig. 7n-p, Suppl. Fig. 2a-d) show typical successions of the event and background layers that characterize sedimentation throughout the Maotianshan Shale Member (e.g., Hu, 2005; Zhao et al., 2012). Event layers are interpreted as resulting from the rapid deposition of suspended mud clouds generated by storms. Polished sections through the marginal area of one rock slab (Fig. 7) show that the WLA belongs to a ca 6-8 $\mathrm{mm}$ thick structureless single-event mudstone layer. The underlying background mudstone layer is darker and contains numerous organic fragments of various origins, most likely algae, detritus, exuviae and fecal strings deposited at the water-sediment interface. The thickness of the original mud layer deposited over the fauna may have attained between 30 and $80 \mathrm{~mm}$, based on estimates proposed by $\mathrm{Hu}$ (2005). We can not rule out the possibility that WLA may represent lag deposits; i.e., organisms winnowed by turbidity currents and subsequently re-deposited. Currents that could deposit ca $80 \mathrm{~mm}$ of mud would have had enough energy to entrain small light-weighted organisms that lived at the water-sediment interface but less likely those supposedly buried in sediment such as worms. The lifestyle of palaeoscolecid worms whether they were truly endobenthic or both endobenthic and epibenthic is open to discussion (see paragraph 5). However, it is certain that buried organisms were less likely to be entrained by currents. Transportation and redeposition processes normally favour extensive dislocation of individuals and generate heterogeneous assemblages made of exoskeletal elements with various origins, size, shape, and weight that are not synchronously deposited and thus have a low probability of being concentrated in very thin layers. These characteristics are not found in WLA or more generally through the Maotianshan Shale Member which typically consists of repeated series of background single-event mudstones (Hu, 2005). The high percentage of incomplete and imperfectly preserved worms suggest that WLA are composed of a majority of individuals that had already started to decay before being buried in sediment. It is neither possible to estimate the frequency of burial events that repeatedly affected the benthic communities of the Chengjiang biota nor to determine the exact time frame (days, months or years) during which the surface of the sea bed remained exposed between two successive events. However, we should consider the possibility that WPA are composed of successive non-contemporaneous populations of organisms that lived and died at or close to the sediment-water interface. If so, the relatively high concentration of worms observed in WLA might be interpreted as resulting from time-averaging. Recent taphonomy experiments conducted with the extant priapulid worm Priapulus caudatus (the closest modern analogue of Cambrian scalidophoran worms) show that a few hours after death the worm body undergoes major distortions a few hours after death and, most of its internal anatomical features are lost completely after 4 days. Fragments of gut structures remains visible up to at least three months. In contrast, the cuticle is resistant to decay for weeks or months after death. These experiments suggest that WLA might associate specimens buried alive with a significant proportion of already dead specimens at variously advanced stage of decay. For this reason, the high concentration of worms observed in WLA may not be a reliable indicator of the density of live individuals in the original population. A post-burial decay cannot be excluded either especially if the overlying sediment layer was relatively thin. In summary, we assume that WLA are autochthonous assemblages that lived at or near the 
water sediment interface, and are composed of living and slightly decayed individuals. The scarcity of arthropod remains in WLA may be explained by assuming that they did not live in the same environment as the worms and lobopodians, or that their locomotion abilities (e.g., crawling and swmming) allowed them to escape mudflows.

\section{Ecology of Cambrian scalidophoran worms}

Scalidophoran worms (Ecdysozoa) were an important and diverse component of the Cambrian marine communities as exemplified by the Chengjiang (e.g., Huang, 2005; Huang et al., 2004a,b, 2006; Han et al., 2007; Maas et al., 2007; Ma et al., 2010) and the Burgess Shale (Conway Morris, 1977; Vannier, 2012; Haug and Haug, 2015; Smith et al., 2015) biotas. These worms share several important features with extant Priapulida (e.g., Van der Land, 1970; Adrianov and Malakhov, 2001; Nielsen, 2001) such as: 1) a non-segmented, annulated, cylindrical body traversed by a straight tubular gut, 2) an introvert with scalid rows and 3) an eversible pharynx lined with cuticular teeth pointing towards the midgut when not everted (Vannier, 2012). Detailed phylogenetic analyses (Harvey et al., 2010; Wills et al., 2012) suggest that these scalidophoran worms (Wills et al., 1998, 2012; Dong et al., 2005, Harvey et al., 2010) are stem-group Priapulida although their precise taxonomy and affinities still need to be clarified. These worms form a relatively heterogeneous and likely polyphyletic group, as exemplified by palaeoscolecids (Harvey et al., 2010; Garcia-Bellido et al., 2013; e.g., Mafangscolex, Fig. 4) which distinguish themselves from other worm groups such as Archaeopriapulidae and Cricocosmiidae (e.g., Han et al., 2007; Wills et al., 2012; Hou et al., 1999) by their unique cuticular pattern of microscopic, tessellating, phosphatic plates. Extant priapulids constitute an important source of information for inferring Cambrian scalidophoran worm ecology. However, the actualistic approach has its limitations and Cambrian worms did not necessarily have the same lifestyles, feeding mode and diet as their modern counterparts. The overall organization of most Cambrian cycloneuralien worms and the various attitudes in which their bodies are fossilized, suggest that these animals had a single body cavity functioning as a hydrostatic skeleton. As in extant priapulids (Vannier et al., 2010, 2012) pressure variations induced by longitudinal and circular cuticular muscles and by retractor muscles (Fig. 8) were likely to have controlled peristaltic movements, proboscis and phraynx invagination and protrusion. This muscular system and hydrostatic skeleton largely determined how these worms could move through the sediment and feed. The cuticle and underlying cuticular muscle system of Priapulus form a very thin layer (ca $120 \mu \mathrm{m}$, Fig. 8e). Our fossil worms do not show details of muscle fibers associated with the cuticle. However, their trunk is outlined by a ca 100-150 $\mu \mathrm{m}$-thick dark or reddish layer (Fig. $3 a-c, 7 e)$ that might incorporate the remains of a fine muscle network comparable to that of Priapulus.

Extant macrobenthic priapulids such as Priapulus live in mud and when they are placed at the sediment surface during experiments, immediately dig into it obliquely and hide themselves deep enough to become invisible after a few tens of seconds. Crawling is performed when conditions for digging are not met (Vannier et al., 2010) and creates branching traces comparable to those observed across the Precambrian-Cambrian boundary and attributed to priapulid-like animals (e.g., treptichnids; Vannier et al., 2010). Extant priapulids do not build well-structured U-shaped burrows (e.g., as in annelids) and often lie in a sub-horizontal position within the sediment (Fig. 8). Recent studies (Zhang et al., 2006; Huang et al., 2014) have convincingly shown that at least two species from the Chengjiang 
biota, Mafangscolex sinensis and Cricocosmia jinningensis, which are both represented in WLA (Figs 3, 4), lived in well-defined burrows. These burrows 1) lied almost parallel to the water sediment interface (WSI) or in a slightly oblique position, 2) were consolidated by possible mucous secretions and 3) were relatively spacious, being larger than its inhabitant, both in diameter and length (Huang et al., 2014). The sub-horizontal position of these burrows does not seem to result from compaction, but more likely reflects the natural habitat and lifestyle of the worms - i.e., sheltering in a ssub-horizontal burrows slightly below the WSI. No remains of such burrows are found in WLA.

The presence of numerous worms within a thin layer may have resulted from compaction, but also from sheltering of the pre-event original population sheltered in subhorizontal burrows at one particular level of the red-ox profile at or below the WSI. They may have preferentially concentrated where physical and chemical conditions were optimal, and/or where food was abundant. The extensive rows of posteriorly pointed sclerites in Cricocosmia seem to have been diametrically opposed and possibly attached to the lateral sides of the animal (Suppl. Fig. 3). Rather than playing a major role in locomotion, such as acting as support for crawling on the sediment surface (Huang et al., 2014; fig. 11), we think that they may have facilitated penetration into the sediment (e.g., possibly tunnelling of horizontal burrows) and anchoring (e.g., preventing back-slippage).

Extant priapulid worms such as Priapulus do have the capacity to catch relatively large prey such as polychaetes worms as attested by undigested chaetae in their gut contents and feces (Vannier, 2012). Priapulus also likely feeds on detritus of various sorts as indicated by the large proportion of undetermined elements in its feces. Similarly, the presence of small invertebrates (e.g., hyolithids, small trilobites, and possible polychetes chaetae; Vannier, 2012) within the gut of Ottoia prolifica from the Middle Cambrian Burgess Shale points to predatorial habits but does not prove that predation was its exclusive feeding mode. Small aggregations of Ottoia specimens around the carapace of the arthropod Sidneyia (Vannier, 2012) indicate possible scavenging habits. In contrast with Ottoia, the precise diet of Cricocosmia and Mafangscolex represented in WLA cannot be inferred from their gut contents which consist of organic-rich material devoid of identifiable elements. This is apparently in contrast with palaeoscolecidan worms such as Palaeoscolex? tenensis from the Lower Ordovician Fezouata Shale which have frequent sediment infillings in their gut and cooccur with Tomaculum-type coproliths (Martin et al., 2016), both features suggesting deposit feeding. The fact that very few worms from WLA have an empty gut would also suggest that they were regular detritus feeders (e.g., surface or subsurface deposit feeders) rather than intermittent predators. The numerous but extremely small pharyngeal teeth of Cricocosmia (Fig. 3d) are more likely to have functionned as a device for scraping or grazing food from decaying material of animal or vegetal origin such as algae, than to have been a raptorial organ. This potential detrital food source is represented in background layers by abundant organic remains (Fig. 7o).

\section{Ecology of Cambrian lobopodians}

Lobopodians are an informal, likely paraphyletic group of still enigmatic early animals that could be roughly depicted as "legged worms" (Hou and Bergström, 1995; Ramsköld and Chen, 1998; Wills et al., 1998; Liu et al., 2011a, b; Legg et al., 2011; Ma et al., 2014; Smith and Hernandez, 2014). Their taxonomy, phylogenetic position within Panarthropoda and possible relationships with extant phyla are not completely understood and have led to 
controversies (e.g., Liu et al., 2011a,b; Legg et al., 2011; Mounce and Wills, 2011). However, convincing fossil evidence from the microstructure of their appendicular sclerites (e.g., Hallucigenia and extant onychophorans have homologous stacked claw elements) and cladistic analysis suggest that some of them might belong to the stem-group Onychophora (Smith and Ortega-Hernandez, 2014). However, the position of large lobopodians such as Jianshanopodia, Megadictyon (Luo et al., 1999; Liu et al., 2006, 2007, 2008, 2013; Vannier et al., 2014), Ayshaeia (Whittington, 1978) and Onychodictyon (Hou et al., 1991; Liu et al., 2008; Ou et al., 2012) within or outside the total group Onychophora (Smith and Hernandez, 2014) needs to be clarified. Although lobopodians display a great variety of shapes and sizes (Liu and Dunlop, 2013), the majority of them have a relatively uniform body plan characterized by a cylindrical body flanked by non-articulated legs and a terminal mouth. Their thin, unsclerotized, annulated cuticle was likely flexible. Lobopodian legs display neither external nor internal articulated features that would recall arthropodial joints. The unique cactus-like external microornament of Diania (Liu et al., 2011; Ma et al., 2014) creates a misleading appearance of articulated joints and is no longer considered as evidence for early arthropodization (Legg et al., 2011; Ma et al., 2014). The only evidence of sclerotization in lobopodians is the presence of terminal claws and dorsal spiny or flattened armature sclerites distributed in pairs that, when present, strengthtened and possibly protected the overall soft body (e.g., Hallucigenia, Microdyction, Onychodictyon). Even the strong prehensile frontal appendages of large lobopodians (e.g., Jianshanopodia, Megadictyon and other xenusiids; (Vannier et al., 2014; Fig. 5l-o) are not fundamentally different from their trunk legs. Extant onychophorans, although terrestrial, not only display phylogenetical relationships with lobopodians but also provide valuable hints about their possible lifestyles. Well-preserved Paucipodia specimens (Fig. 5a-e; for general morphology see Chen et al., 1995, 2002; Luo et al., 1999; Hou et al., 2004; Liu and Dunlop, 2013) reveal important aspects of the functional morphology of lobopodians. As in extant onychophorans (Brusca and Brusca, 2003; Snodgrass, 1938), the body cavity of Paucipodia extended deeply into the legs with no trace of partitioning and is likely to represent a unique coelomic or hemocoelic fluid-filled cavity. The possible connective tissues that enveloped its gut ran through the central part of its legs and clearly attached to the basal part of claws (Fig. 5b, c, e). These tissues have no exact equivalent in extant ecdysozoans and are difficult to characterize. However, their attachment to the claws recalls that of the retractor muscles in extant onychophorans which go through the legs and play a key role in claw retraction and leg elevation (e.g., de Sena Oliveira and Mayer, 2013). Similar tissues also occur within the legs of other lobopodians irrespective of their size (e.g., large xenusiid; Fig. 5m-o and Vannier et al., 2014) and may have been of functional importance in the locomotion of numerous species. All lobopodians seem to have possessed a hydrostatic skeleton comparable with that of extant onychophorans - i.e., force was not transmitted via stiff skeletal elements as in arthropods but mainly by the internal pressure of an assumed incompressible coelomic fluid (Kier, 2012). Muscles are likely to have deformed this hydrostatic skeleton, resulting in leg retraction while walking or the stiffening of prehensile appendages in large lobopodians (Fig. 5l, m). The annulated nature of lobopodians (trunk and appendages) would suggest that lobopodians had underlying cuticular muscle fibers comparable with those of scalidophoran worms (Fig. 8). As for worms (see previous section) direct evidence for a cuticular muscle network is not obtainable from our fossil material. If present, this muscle layer would have been very thin, and possibly represented by the reddish outline of the body (Fig. 5a). The support, locomotion and possibly feeding 
mechanisms of lobopodians were not governed by the same physical principles as for arthropods which flex their limbs via muscles attached to the inner side of their jointed exoskeleton. Their overall functional morphology may have been close to that of scalidophoran worms, with a hydrostatic skeleton and muscles producing body elongation, shortening and bending. The only major difference is that the worms interacted with the ediment via a large contact surface whereas lobopodians contacted the substrate via the tips of their legs. Lobopodians were likely the very first walkers and climbers on the seafloor. Their sickle-like claws, resembling those of extant onychophorans, indicate abilities to cling to hard substrates including the dead or living bodies of other animals (e.g., sponges and carcasses).

Most lobopodians had a differentiated feeding apparatus in the form of a terminal radial mouth and a pharyngeal-like organ. In smaller forms such as Hallucigenia sparsa, the assumed pharynx was lined with microscopic denticles that seem to have been involved in food transfer and processing (Smith and Caron, 2015). Large lobopodians such as Jianshanopodia had a more spacious funnel-shaped pharyngeal structure lined with strong teeth (Vannier et al., 2014; fig 4). Comparable open conical structures occur in Onychodictyon ferox and undetermined xenusiids from WLA (Fig. $5 \mathrm{i}$, j and I, m), respectively. These features indicate that most lobopodians were able to ingest and probably reduce food particles or small prey in proportion to their body size. Digestive glands found in Megadictyon cf. haikouensis and Pambdelurion whittingtoni (Vannier et al., 2014) suggest that some large lobopodians had evolved capacities for carnivory and macrophagy. These glands are absent in the majority of lobopodians, especially small forms interpreted as stem group onychophorans (Smith and Ortega-Hernandez, 2014). The featureless gut contents of lobopodians have until now not provided precise information about their diet and feeding types, unlike Cambrian priapulids (Vannier, 2012) and euarthropods (Zacaï et al., 2015). In the absence of direct evidence, attempts to infer lobopodian feeding relationships and lifestyles have been made from their supposed faunal associates (e.g., Whittington, 1978; Conway Morris, 1997; Budd, 2001). The co-occurrence of numerous Hallucigenia sparsa specimens with animal remains has been considered as an indicator of scavenging habits and congregation over decaying material (Conway Morris, 1977; Suppl. Fig. 4a-d). The frequent association of Ayshaeia pedunculata with sponge remains has led $\mathrm{H}$. Whittington (1978) to suggest that this iconic lobopodian from the Burgess Shale could climb and anchor on sponges by using its claws and possibly fed on sponge soft tissues. Relatively large patches of sponge tissue pressed against the trunk and legs of Ayshaeia support this hypothesis (Suppl. Fig. 4e-g). However, the alimentary canal of Ayshaeia lacks spicules that would confirm the effective ingestion of sponge tissues. Recurrent associations of Microdictyon sinicum from the Chengjiang biota with eldoniids (Chen et al., 1995) are equally difficult to interpret. Recent interpretations of eldoniids as benthic tentaculate deposit feeders (Dzik et al., 1997; Caron et al., 2010) rather than pelagic filter feeders (Durham, 1974) do not support the supposed epipelagic lifestyle of lobopodians such as Microdyction (see also Liu et al., 2008). It is therefore more likely that Microdictyon fed on eldoniid carcasses deposited on the seafloor.

\section{Ecological interactions between lobopodians and worms?}

Taphonomy suggests that WLA scalidophoran worms and lobopodians were buried in situ and probably shared the same habitat -i.e., a muddy substrate scattered with various animal 
(e.g., decaying carcasses) and vegetal (e.g., algal filaments) debris. This probable abundant food source regularly deposited at the water-sediment interface is likely to have been exploited by both animal groups. Subhorizontal tunnelling through sediment as suggested by Huang et al. (2014) from detailed fossil evidence, may have allowed worms to feed on various organic remains superficially buried in mud. The smallest lobopodians (e.g., Microdyction) were likely detritus feeders, scavengers, or micropredators (e.g., on meiofaunal organisms or sponge tissues). Their relatively simple mouthparts and lack of strong prehensile appendages probably limited their ability to dilacerate tissues and to ingest large food fragments. Only large xenusiids (Fig. 5) and possibly other forms such as Onychodictyon may have evolved different feeding modes, including scavenging and predation. Xenusiids had flexible prehensile frontal appendages armed with claws (Fig. 5l-o) and digestive glands indicating possible macrophagy (Vannier et al. 2014). It is possible that some lobopodians fed on worms. However, no undigested worm sclerites have yet been found in their gut. Nutrient-rich patches such as animal carcasses often attract large populations of extant annelid worms (e.g., Rouse et al., 2004) and other opportunistic scavengers. Similarly, locally concentrated food might have attracted worms and some of their faunal associates such as lobopodians to form large aggregations of individuals. WLA animals had no visual organs and are likely to have relied on chemical information to locate food. In summary, chemical attraction to food rather than hypothetical prey-predator relationships may have brought worms and lobopodians together and in relatively high spatial concentration.

\section{A hypothetical "pre-arthropodian world" ?}

Recent evolutionary trees using both fossil and molecular records (Erwin et al., 2011; Erwin and Valentine, 2013) place the origin of ecdysozoans and their early diversification in the Ediacaran. These predictions and divergence times based on molecular clocks still lack strong support from palaeontological data. Trace fossils do attest to the presence of ecdysozoan groups such as priapulid-like scalidophoran worms at the Precambrian-Cambrian boundary (Vannier et al., 2010) and even earlier (e.g., Buatois and Mangano, 2004, 2011). Kinorhynchlike (Zhang et al., 2015) and priapulid-like (Liu et al., 2014) scalidophoran animals also occur as 3D-preserved body fossils in the 535 million year old Kuanchanpu Formation from China (lowermost Cambrian equivalent of Fortunian Stage) but so far have not been found with arthropod remains. Eurarthropods are known from the early Cambrian onwards, as exemplified by the first trilobites appearance near the base of Series 2, above the Fortunian. This points to the possibility that during a time interval preceding Cambrian Stage 2, marine ecosystems may have been devoid of arthropods being mainly occupied by non-arthropod ecdysozoans such as scalidophoran worms and lobopodians. These two animal groups shared important common features (Fig. 10) such as the lack of jointed sclerites, a hydrostatic skeleton, and an annulated body likely structured by probable cuticular longitudinal and circular muscle fibers. These soft-bodied animals appear as ecological pioneers, with scalidophoran worms as the first burrowers and bioturbators (Vannier et al., 2010) and important players in the "Agronomic" or "Cambrian Substrate" revolution (e.g., Seilacher and Pflüger, 1994; Seilacher, 1999; Bottjer et al., 2000; Dornbos et al., 2004, 2005) and with lobopodians as supposedly the first sea-floor walkers and climbers. Their functional morphology and ecology were probably very different from those of euarthropods. The articulated sclerites and associated muscles of true arthropods marked a turning point in the 
evolution of ecdysozoans, opening up new possibilities particularly for locomotion (e.g., swimming and colonization of the water column; Vannier et al., 2009) and food manipulation and processing (e.g., hard prehensile appendages and mouth parts). The hypothesis of a "pre-arthropodan ecology" should be seriously considered but clearly requires more adequate testing with fossil data.

\section{Acknowledgements}

This work was funded by the Agence Nationale de la Recherche (ANR-11-BS-56-0025; RALI, Rise of Animal Life). J.V. is grateful to Jianni Liu and Jian Han (Northwest University, Xi'an; Eraly Life Institute) and to Douglas Erwin and Mark Florence (Smithsonian National Museum of Natural History, Washington D.C.) for access to the palaeontological collections and for their permission to study the fossil material (JV's visits to Xi'an in Oct. 2012 and Dec. 2013), to the Museum of Comparative Zoology (MCZ, Yale University, Cambridge, Mass., USA) for photographs, and to the Centre Technologique des Microsctrutures (CT $\mu$; University Claude Bernard Lyon 1) for use of SEM facilities and technical assistance. J.V. is also thankful to Fredrik Pleijel, Sylve Robertsson, Stefan Agrenius and Alexander Tzetlin and colleagues for his research visits to the Sven Love'n Center for Marine Sciences, Sweden and the Nikolai Pertsov White Sea Biological Station, Russia, and to Matthew Makou for correcting our manuscript. 


\section{References}

Adrianov, A.V., Malakhov, V.V. 2001. Symmetry of priapulids (Priapulida). 1. Symmetry of adults. Journal of Morphology 247, 99-110.

Bottjer, D.J., Hagadorn, J.W., Dornbos, S.Q., 2000, The Cambrian substrate revolution: GSA Today 10, 1-7.

Brusca, R.C., Brusca, G.J. 2002. Invertebrates. Sinauer, Sunderlang, Mass. (936 p.).

Buatois, L.A., Mángano, M.G., 2004. Terminal Proterozoic-Early Cambrian ecosystems: Ichnology of the Puncoviscana Formation, Northwest Argentina. Fossils \& Strata 51, 1-16.

Buatois, L.A., Mángano, M.G., 2011. Ichnology: Organism-substrate interactions in space and time. Cambridge University Press, Cambridge. (487 p.).

Budd, G.E., 2001. Tardigrades as 'stem-group arthropods': the evidence from the Cambrian fauna. Zool. Anz. 240, 265-279.

Caron, J.B, Conway Morris, S., Shu D.-G., 2010. Tentaculate fossils from the Cambrian of Canada (British Columbia) and China (Yunnan) interpreted as primitive deuterostomes. PLoS ONE 5, e9586.

Chen, J.Y., 2004. The Dawn of Animal World. Jiangsu Science and Technology Press, Nanjing (In Chinese). (366 p.).

Chen, J.-Y., 2009. The sudden appearance of diverse animal body plans during the Cambrian explosion. International Journal of Developmental Biology 53: 733-751.

Chen J.-Y., Erdtmann, B.D., 1991. Lower Cambrian Lagerstätte from Chengjiang, Yunnan, China. In: Simonetta, A.M., Conway Morris S. (Eds), The early evolution of metazoans and the significance of problematic taxa. Cambridge University Press, Cambridge, pp. 57-76.

Chen, J.-Y., Hou, X.-G., Lu, H.-Z., 1989. Early Cambrian netted scale-bearing worm-like sea animal. Acta Palaeontologica Sinica 28, 1-16.

Chen, J.-Y., Huang ,D.-Y, Peng, Q.-Q, Chi H.-M., Wang X.-Q., 2003. The first tunicate from the Early Cambrian of South China. Proceedings of the National Academy of Sciences of the United States of America 100, 83148318.

Chen, J.-Y., Zhou, G.-Q., Ramsköld, L., 1995a. The Cambrian lobopodian Microdictyon sinicum. Bulletin of the National Museum of Natural Science 5, 1-93 (Taichung, Taiwan).

Chen, J.-Y., Zhou, G.-Q., Ramsköld, L., 1995b. A new Early Cambrian onychophoran-like animal, Paucipodia gen. nov., from the Chengjiang fauna, China. Transactions of the Royal Society Edinburgh: Earth Sciences 85, 275-282.

Chen, L.-Z., Luo, H.-L., Hu, S.-X., Yin, J.-Y., Jiang, Z.-W., Wu, Z.-L., Li, F., Chen, A.-L., 2002. Early Cambrian Chengjiang Fauna in Eastern Yunnan, China. Yunnan Science and Technology Press, Kunming (In Chinese, with English summary).

Conway Morris, S., 1977. A new metazoan from the Burgess Shale of British Columbia. Palaeontology 20, 623640.

Daley, A.C., Budd, G.E., Caron, J.-B., Edgecombe, G.D., Collins, D. 2009. The Burgess Shale anomalocaridid Hurdia and its significance for early euarthropod evolution. Science 323, 1597-1600.

De Sena Oliveira, I., Mayer, G., 2013. Apodemes associated with limbs support serial homology of claws and jaws in Onychophora (velvet worms). Journal of Morphology 274, 1180-1190.

Dong, X.-P., Donoghue, P.C.J., Cunningham, J.A., Liu, J.B., Cheng, H., 2005. The anatomy, affinity, and phylogenetic significance of Markuelia. Evol. Dev. 7, 468-482.

Dornbos, S.Q., Bottjer, D.J., Chen, J.Y., 2004. Evidence for seafloor microbial mats and associated metazoan lifestyles in Lower Cambrian phosphorites of Southwest China. Lethaia 37, 127-137.Dornbos, S.Q., Bottjer, D.J., Chen, J.Y., 2005. Paleoecology of benthic metazoans in the Early Cambrian Maotianshan Shale biota and the Middle Cambrian Burgess Shale biota: evidence for the Cambrian substrate revolution. Palaeogeography, Palaeoclimatology, Palaeoecology 220, 47-67.

Dunn, C.W. et al., 2008. Broad phylogenomic sampling improves resolution of the animal tree of life. Nature $452,745-750$.

Dunne, J.A., Williams, R.J., Martinez, N.D., Wood, R.A., Erwin, D.H., 2008. Compilation and network analyses of Cambrian food webs. PLOS Biol 6, e102.

Durham, J.W., 1974. Systematic position of Eldonia ludwigi Walcott. Journal of Paleontology 48, 750-755.

Dzik, J., Zhao, Y.-L., Zhu, M.-Y., 1997. Mode of life of the Middle Cambrian eldonioid lophophorate Rotadiscus. Palaeontology 40, 385-396.

Edgecombe, G. D. 2009. Palaeontological and molecular evidence linking arthropods, onychophorans, and 
other Ecdysozoa. Evolution Education Outreach 2, 178-190.

Erwin, D.H., Laflamme, M., Tweedt, S.M., Sperling, E.A., Pisani, D., Peterson, K.J., 2011. The Cambrian conundrum: Early divergence and later ecological success in the early history of animals. Science 334,10911097.

Erwin, D.H., Valentine, J.W., 2013. The Cambrian Explosion and the Construction of Animal Biodiversity. Roberts \& Company, Colorado. (406 p.).

Gabbott, S.E., Hou, X.G., Norry, M.J., Siveter, D.J., 2004. Preservation of Early Cambrian animals of the Chengjiang biota. Geology 32, 901-904.

Gaines, R.R., Hammarlund, E.U., Hou, X.-G., Qi, C.S., Gabbott, S.E., Zhao, Y.-L., Peng, J., Canfield, D.E., 2012. Mechanism for Burgess Shale-type preservation. Proceedings of the National Academy of Sciences of the United States of America 103, 15759-15764.

Garcia-Bellido, D.C., Paterson, J.R., Edgecombe, G.D, 2013. Cambrian palaeoscolecids (Cycloneuralia) from Gondwana and reappraisal of species assigned to Palaeoscolex. Gondwana Research 24, 780-795.

Han, J., Liu, J.-N., Zhang, Z.-F., Zhang, X.-L., Shu, D.-G., 2007. Trunk ornament on the palaeoscolecid worms Cricocosmia and Tabelliscolex from the Early Cambrian Chengjiang deposits of China. Acta Palaeontologica polonica 52, 423-431.

Harvey, T.H.P., Dong,, X.-P., Donoghue, P.C.J., 2010. Are palaeoscolecids ancestral ecdysozoans? Evol. Dev. 12,177-200.

Haug, J.T., Haug, C., 2015. A new cycloneuralian from the Burgess Shale with a palaeoscolecid-type terminal end. N. JB. Geol. Paläont. Abh. 274, 73-79.

Hou, X.-G, Ramsköld, L, Bergström, J., 2001. Composition and preservation of the Chengjiang fauna- a lower Cambrian soft-bodied biota. Zoologica Scripta 20, 395-411.

Hou, X.-G, Sun W.-G., 1988. Discovery of Chengjiang fauna at Meishucun, Jinning, Yunnan. Acta Palaeontologica Sinica 27, 1-12.

Hou, X.-G., Bergström, J., 1995. Cambrian lobopodians-ancestors of extant onychophorans? Zoological Journal of the Linnaean Society 114, 3-19.

Hou, X.-G., Bergström, J., Ma, X.Y., Zhao, J., 2006. The lower Cambrian Phlogites Luo and Hu re-considered. GFF $128,47-51$.

Hou, X.-G., Bergström, J., Wang, H.-F., Feng, X.-H., Chen, A.L., 1999. The Chengjiang Fauna - Exceptionally wellpreserved animals from 530 millions years ago (In Chinese with English abstract). Yunnan Science and Technology Press, Kunming. (170 p.).

Hou, X.-G., Ma, X.-Y., Zhao, J., Bergström, J., 2004. The lobopodian Pancipodia inermis from the Lower Cambrian Chengjiang fauna, Lower China. Lethaia 37, 235-244.

Hou, X.-G., Ramsköld, L., Bergström, J., 1991. Composition and preservation ofthe Chengjiang fauna-a lower Cambrian soft-bodied biota. Zoologica Scripta 20, 395-411.

Hou, X.-W., Aldridge, R.J., Bergström, J., Siveter, David J., Siveter, Derek J., Feng, X.-H. 2004. The Cambrian fossils of Chengjiang, China - The flowering of early animal life. Blackwell. (233 p.).

Hu, S.-X., 2005. Taphonomy and Palaeoecology of the Early Cambrian Chengjiang Biota from Eastern Yunnan, China. Berliner Paläontologische Abhandlungen 7, 1-188.

Huang, D.-Y., 2005. Early Cambrian worms from SW China: Morphology, systematics, lifestyles and evolutionary significance. Unpublished PHD-thesis, Université Claude Bernard Lyon 1. (245 pp.).

Huang, D.-Y., Chen, J.-Y., Vannier, J., 2006b. Discussion on the systematic position of the Early Cambrian priapulomorph worms. Chin. Sci. Bull. 51: 243-249.

Huang, D.-Y, Chen, J.-Y., Zhu, M.-Y., Zhao, F.-C., 2014. The burrow dwelling behavior and locomotion of palaeoscolecidian worms: New fossil evidence from the Cambrian Chengjiang fauna. Palaeogeography, Palaeoclimatology, Palaeoecology 398, 154-164.

Huang, D.-Y., Vannier, J., Chen, J.-Y., 2004a. Anatomy and lifestyles of Early Cambrian priapulid worms exemplified by Corynetis and Anningvermis from the Maotianshan Shale (SW China). Lethaia 37, 21-33.

Huang, D.-Y., Vannier, J., Chen, J.-Y., 2004b. Recent Priapulidae and their Early Cambrian ancestors: comparisons and evolutionary significance. Geobios 37, 217-228.

Kier, W.M., 2012. The diversity of hydrostatic skeletons. Journal of Experimental Biology 215, 1247-1257.

Legg, D.A., Ma, X.Y., Wolfe, J.M., Ortega-Hernández, J., Edgecombe, G.D., Sutton, M.D., 2011. Lobopodian phylogeny reanalysed. Nature 476, E2.

Legg, D.A., Sutton, M.D., Edgecombe, G.D., Caron, J.-B. 2012. Cambrian bivalved arthropod reveals origin of arthrodization. Proceedings Royal Society London B. 1958, 4699-4704.

Liu, J.-N., Dunlop, J.A., 2014. Cambrian lobopodians: A review of recent progress in our understanding of their morphology and evolution. Palaeogeography, Palaeoclimatology, Palaeoecology 398, 4-15. 
Liu, J.-N., Shu, D.-G., Han, J., Zhang, X.F., Zhang, X.L., 2008. Origin, diversification and relationships of Cambrian lobopods. Gondwana Research 14, 277-283.

Liu, J.-N., Shu, D.-G., Han, J., Zhang, Z.-F., Zhang, X.-L., 2006. A large xenusiid lobopod with complex appendages from the Chengjiang Lagerstätte (Lower Cambrian, China). Acta Palaeontologica Polonica 51, 215-222.

Liu, J.-N., Shu, D.-G., Han, J., Zhang, Z.-F., Zhang, X.-L., 2007. Morpho-anatomy of the lobopod Megadictyon cf. haikouensis from the Early Cambrian Chengjiang Lagersträtte, South China. Acta Zoologica 88, 209-288.

Liu, J.-N., Steiner, M., Dunlop, J.A., Keup, H., Shu, D-.G., Ou, Q., Han, J., Zhang, Z.-F., Zhang, X.-L., 2011b. ReplyReplying to Mounce, C.P., M. Wills. Nature 476. http://dx.doi.org/10.1038/nature10266 and Legg, D.A., et al. Nature 476, http://dx.doi.org/10.1038/nature10267. Nature 476, E3-E4.

Liu, J.-N., Steiner, M., Dunlop, J.A., Keup, H., Shu, D.-G., Ou, Q., Han, J., Zhang, Z.-F., Zhang, X.-L., 2011a. An armoured Cambrian lobopodian from China with arthropod-like appendages. Nature 470, 526-530.

Liu, Y.-H., S. H. Xiao, S.-H., T. Q. Shao, T.-Q, J. Broce J., Zhang, H.-Q. 2014. The oldest known priapulid-like scalidophoran animal and its implications for the early evolution of cycloneuralians and ecdysozoans. Evolution and Development 16, 155-165.

Luo, H.-L., Hu, S.-X., Chen, L.-Z., Tao, Y.-H., 1999. Early Cambrian Chengjiang Fauna from Kunming Region, China. Yunnan Science and Technology Press, Kunming (In Chinese, with English summary). (129 p.).

Ma, X.-Y., Edgecombe, G.D., Legg, D.A., Hou, X.-G., 2014. The morphology and phylogenetic position of the Cambrian lobopodian Diania cactiformis. Journal of Systematic Palaeontology 12, 445-457.

Ma, X.-Y., Hou, X.-G., Baines, D., 2010. Phylogeny and evolutionary significance of vermiform animals from the Early Cambrian Chengjiang Lagerstatte. Sci. China Earth. Sci. 53, 1774-1783.

Martin, E.L.O., Pittet, B., Gutiérrez-Marco, J.-C., Vannier, J., El Hariri, K., Lerosey-Aubril, R., Masrour, M., Nowak, H., Servais, T., Vandenbroucke, T.R.A., Van Roy, P., Vaucher, R., Lefebvre, B. 2016a in press. The Lower Ordovician Fezouata Konservat-Lagerstätte from Morocco: Age, environment and evolutionary perspectives. Gondwana Research.

Martin, E.L.O., Lerosey-Aubril, R., Vannier, J. 2016b in press. Palaeoscolecid worms from the lower Ordovician Fezouata Lagerstätte, Morocco: Palaeoecological and palaeogeographical implications. Palaeogeogr. Palaeoclimatol. Palaeoecol.

Maas, A., Huang, D.-Y., Chen, J.-Y., Waloszek, D., Braun, A., 2007. Maotianshan Shale nemathelminths morphology, biology, and the phylogeny of nemathelminthes. Palaeogeogr. Palaeoclimatol. Palaeoecol. 254, 288-306.

Mounce, R.C.P.,Wills, M.A., 2011. Phylogenetic position of Diania challenged.Nature 476, E1.

Nielsen, C., 2001. Animal Evolution: Interrelationships of the living phyla. Oxford University Press. (563 p.).

Ou, Q., Shu, D.-G., Mayer, G., 2012. Cambrian lobopodians and extant onychophorans provide new insights into early cephalization in Panarthropoda. Nature Communication 3 (1261), 1-6.

Ramsköld, L., Chen, J.Y., 1998. Cambrian Lobopodians: morphology and phylogeny. In: Edgecombe, G.D. (Ed.), Arthropods Fossils and Phylogeny. Columbia University Press, New York, pp. 107-150.

Seilacher, A. 1999. Biomat-related lifestyles in the Precambrian. Palaios 14, 86-93.

Seilacher, A., Pflüger, F. 1994. From biomats to benthic agriculture: a biohistoric revolution. In: Krumbein, W.E, Peterson, D.M., Stal, L.J. (Eds), Biostabilization of sediments, Bibliotheks und Informationssystem der Carl von Ossietsky Univesität Odenburg.

Smith, M.R., 2015. A palaeoscolecid worm from the Burgess Shale. Palaeontology 58, 973-979.

Smith, M.R., Caron, J.-B., 2015. Hallucigenia's head and the pharyngeal armature of early ecdysozoans. Nature 523, 75-79.

Smith, M.R., Harvey, T.H.P., Butterfield, N.J., 2015. The macro- and microfossil record of the Cambrian priapulid Ottoia. Palaeontology 58, 705-721.

Smith, M.R., Ortega-Hernandez, J., 2014. Hallucigenia's onychophoran-like claws and the case of Tactopoda. Nature 514, 363-367.

Snodgrass, R.E., 1938. Evolution of the Annelida, Onychophora and Arthropoda. Smithsonian Miscellaneous Collections 97, 1-159.

Sorensen, M.V., Hebsgaard, M.B., Heiner, I., Glenner, H., Willerslev, E., Kristensen, R.M., 2008. New data from an enigmatic phylum: evidence from molecular sequence data supports a sister-group relationship between Loricifera and Nematomorpha. J. Zoolog. Syst. Evol. Res. 46, 231-239.

Steiner, M, Zhu M.-Y., Zhao Y.-L., Erdtmann B.D., 2005. Lower Cambrian Burgess Shale-type fossil associations of South China. Palaeogeography, Palaeoclimatology, Palaeoecology 220, 129-152.

Telford, M.J., Bourlat, S.J., Economou, A., Papillon, D., Rota-Stabelli, O., 2008. The evolution of Ecdysozoa. Philosophical Transaction of the Royal Society B. 363, 1529-1537.

Van Der Land, J. 1970. Systematics, zoogeography and ecology of the Priapulida. Zool. Verhandel. 112, 1-118. 
Vannier, J., Garcia-Bellido, D., Hu, S.-X., Chen, A.-L., 2009. Arthropod visual predators in the early pelagic ecosystem: evidence from the Burgess Shale and Chengjiang biotas. Proceedings of the Royal Society London B 276, 2567-2574.

Vannier, J., 2012. Gut contents as direct indicators for trophic relationships in the Cambrian marine ecosystem. Plos One 7, e52200.

Vannier, J., Calandra, I., Gaillard, C., Zylinska, A., 2010. Priapulid worms: Pioneer horizontal burrowers at the Precambrian-Cambrian boundary. Geology 38, 711-714.

Vannier, J., Liu, J.-N., Lerosey-Aubril, R., Vinther, J., Daley, A.C., 2014. Sophisticated digestive systems in early arthropods. Nature Communications 5, 3641.

Vinther, J., Stein, M., Longrich, N.R., Harper, D.A.T., 2014. A suspension-feeding anomalocarid from the Early Cambrian. Nature 507, 496-500.

Whittington, H.B., 1978. The lobopodian animal Aysheaia pedunculata Walcott, Middle Cambrian, Burgess Shale, British Columbia. Philosophical Transactions of the Royal Society of London B 284, 165-197.

Wills, M.A, Gerber, S., Ruta, M., Hughes, M., 2012. The disparity of priapulid, archaeopriapulid and palaeoscolecid worms in the light of new data. Journal of Evolutionaty Biology 25, 2056-2076.

Wills, M.A., 1998. Cambrian and recent disparity: the picture from priapulids. Paleobiology 24, 177-199.

Zacaï, A., Vannier, J., Lerosey-Aubril, R., 2016. Reconstructing the diet of a 505-million-year-old arthropod: Sidneyia inexpectans from the Burgess Shale fauna, Arthropod Structure \& Development 45, 200-220.

Zhang, X.-G., Aldridge, R.J., 2007. Development and diversification of trunk plates of the Lower Cambrian lobopodians. Palaeontology 50, 401-415

Zhao, F.-C., Hu, S.-X., Caron, J.B., Zhu, M.-Y., Yin Z.-J., Lu, M.-A., 2012. Spatial variation in the diversity and composition of the Lower Cambrian (Stage 3) Chengjiang biota, Southwest China. Palaeogeography, Palaeoclimatology, Palaeoecology 346, 54-65.

Zhang, H.-S., Xiao, S., Liu, Y., Yuan, X., Wan, B.Muscente, A., Shao, T., Gong, H., G. Cao, G. 2015. Armored kinorhynch-like scalidophoran animals from the early Cambrian. Scientific Reports 5.

\section{EXPLANATION OF TEXT-FIGURES}

Fig. 1. Worm-lobopodian association (WLA) from the Chengjiang biota (Early Cambrian; Yunnan Province, China), ELI-JS0001 (three pieces). (a), (b) ELI-JS0001C, general view of the rock slab and line-drawing. (c)-(f) ELI-JS0001A, B, general view of slab, group of worms (Cricocosmia), composite line-drawing from part and counterpart and details of Paucipodia. All light photographs. Abbreviations: gu, gut tract; le, leg; ph, pharynx; Phl, Phlogites; sc, sclerite (Cricocosmia); tr, trunk. Scale bars: $10 \mathrm{~mm}$ in a-c, e; $5 \mathrm{~mm}$ in d, f.

Fig. 2. Worm-lobopodian associations (WLA) from the Chengjiang biota (Early Cambrian; Yunnan Province, China). (a), (b) XDB-2040B, general view of the rock slab and line-drawing. (c), (d) ELI-MF016A, general view and line-drawing. (e), (f) ELI-JS002, general view and linedrawing. All light photographs. Abbreviation: Phl, Phlogites. Scale bars: $1 \mathrm{~cm}$.

Fig. 3. Cricocosmia jinningensis, Chengjiang biota (Early Cambrian; Yunnan Province, China). (a)-(c) In WLA, ELI-JS0001A, general view, details of juvenile specimen, details of sclerites in a subadult specimen. (d)-(h) General morphology of isolated specimens (not WLA). (d) ELI-0001402 with everted pharynx. (e), (f) ELI-000-1400, coiled specimen showing well-preserved annulations and a double row of sclerites, general view and details of sclerites (white arrows). (g), (h) ELI-000-1401, details of the double row of sclerites (arrows). All light photographs. Abbreviations: al, algae; an, annulations gu, gut; ju, juvenile; ph, pharynx; prs, proboscis spines; sc, sclerite. Scale bars: $1 \mathrm{~cm}$ in a; $5 \mathrm{~mm}$ in b, d, e; $1 \mathrm{~mm}$ in c, f-h. 
Fig. 4. Mafangscolex sinensis in WLA from the Chengjiang biota (Early Cambrian; Yunnan Province, China). (a) ELI-JS0001B, three specimens associated with Cricocosmia. (b) ELIJS0001A showing very narrow annulations. (c)-(e) ELI-JS0074, fragment of cuticle with closely packed platelets (arrows indicate boundaries between annuli), details of platelet with central tubercle. $a, b$ are light photographs. c-e are SEM images. Abbreviations: $\mathrm{cm}$, clay minerals; cr, Cricocosmia; gu, gut; pa, Mafangscolex. Scale bars: $1 \mathrm{~cm}$ in a-c; $1 \mathrm{~mm}$ in b; 100 $\mu \mathrm{m}$ in $\mathrm{d} ; 30 \mu \mathrm{m}$ in e.

Fig. 5. Lobopodians in WLA from the Chengjiang biota (Early Cambrian; Yunnan Province, China). (a)-(e) Paucipodia haikouensis, ELI-JS0001A, general view and simplified drawing showing internal organization, details of two claw-bearing lobopods, diagrammatic transverse section through trunk. (f)-(h) Onychodictyon ferox, ELI-MF016A, B; general view, details of annulated lobopods. (i)-(k) Onychodictyon ferox, ELI-JS0074, details of the head region showing possible funnel-shaped pharynx, photograph and simplified drawing. (I)-(o) Undetermined xenusiid lobopodian, ELI-JS0001C, simplified drawing and photograph, details of finely annulated lobopods. All light photographs. Abbreviations: an, annulations; cc, coelomic cavity; cl, claw; ct, assumed connective tissues; cu, cuticle; ds, dorsal sclerite; eb?, possible epibionts; fa, frontal appendage; fs, fiber-like structure; gu, gut; lo1-lo5, 1st to 5th pair of lobopods; m, mouth; mu?, possible muscles; oe?, possible oesophagus; pa, papillae; ph, pharynx. Scale bars: $10 \mathrm{~mm}$ in a, b, l-o; $5 \mathrm{~mm}$ in $\mathrm{f}-\mathrm{h} ; 1 \mathrm{~mm}$ in c, e, i, j.

Fig. 6. Other organisms in WLA from the Chengjiang biota (Early Cambrian; Yunnan Province, China). (a) ELI-JS002, Phlogites longus, two individuals bearing a long stolon, with adjacent almost complete Microdictyon. (b) ELI-JS0001C, undetermined inarticulate brachiopod. (c) Naraoiid arthropod (juvenile). (d) ELI-JS0001B, algal filaments. All light photographs. Abbreviations: af, algal filaments; as, anterior shield; ca, calyx-like structure; $\mathrm{Cr}$, Cricocosmia; lop?, possible lophophore; Mi, Microdictyon; na?, possible naraoiid arthropod; Phl, Phlogites; ps, posterior shield; sc, sclerites; sp, stomacal pouch; st, stolon. Scale bars: $1 \mathrm{~cm}$ in a-c; $1 \mathrm{~mm}$ in $\mathrm{d}$.

Fig. 7. Fossil preservation in WLA from the Chengjiang biota (Early Cambrian; Yunnan Province, China). (a)-(d) ELI-JS0074A, group of slightly decayed worms (Cricocosmia jinningensis), details of gut (see location in a), EDX analysis and details of carbonaceous film (see location in b). (e)-(m) ELI-JS0074B, fragment of Cricoscomia. (e)-(g) General view, details (see area in e), and elemental mapping of $\mathrm{O}, \mathrm{Si}, \mathrm{Al}, \mathrm{C}$ and Fe. (h)-(j) Clusters of iron oxide spherules (see location in $f$ ), morphology and EDX analysis of one spherule. (k)-(m) Fragment showing clay minerals on the external surface of the worm and within the rock matrix, details of surface. ( $n$ )-(p) ELI-JS0074, polished sections through WLA (red arrows; ELIJS0074A and B are the part and counterpart, respectively), general view and details. a, e, $n-p$ are light photographs; b, d, h, i, f, k-m are SEM images. Abbreviations: bgl, background layer; cf, carbonaceous film; ctp, counterpart; evl, event layer; gu, gut; io, iron oxide; ph, pharynx; $\mathrm{pt}$, part; sb, sharp boundary between the top of background layer and base of single-event layer; sc, sclerite; ws, worm surface. Scale bars: $1 \mathrm{~cm}$ in a, n; $5 \mathrm{~mm}$ in o, p; $1 \mathrm{~mm}$ in e; $500 \mu \mathrm{m}$ in $\mathrm{b}, \mathrm{f}, \mathrm{g} ; 100 \mu \mathrm{m}$ in $\mathrm{h} ; 50 \mu \mathrm{m}$ in $\mathrm{d} ; 30 \mu \mathrm{m}$ in $\mathrm{l} ; 5 \mu \mathrm{m}$ in $\mathrm{m} ; 10 \mu \mathrm{m}$ in i, k.

Fig. 8. Muscular network in Priapulus caudatus. (a) Annulated trunk. (b) Details of the inner surface of the trunk showing longitudinal muscles and retractor muscle attached to cuticle 
(white arrows indicate annulus boundary). (c), (d) Trunk fragment (annulus in light orange). (e), (f) Longitudinal and circular muscle fibers in transverse section. (g), (h) retractor muscle attached to cuticle. $a, b, h$ are light photographs. b, c-g are SEM images. Abbreviations: an, annulus; $\mathrm{cm}$, circular muscle fibers; is, inner surface; Im, longitudinal muscle fibers; os, outer surface; rm, retractor muscles. Scale bars: $2 \mathrm{~mm}$ in a, h, $1 \mathrm{~mm}$ in b, c, g, $500 \mu \mathrm{m}$ in d, $50 \mu \mathrm{m}$ in $\mathrm{f}, 20 \mu \mathrm{m}$ in e.

Fig. 9. Burrowing of Priapulus caudatus. (a)-(f) In laboratory conditions, showing oblique digging in mud. (g)-(i). In its natural habitat (muddy intertidal environment) near the White Sea Biological Station (Kandalaksha Bay of the White Sea, Russia ; $66^{\circ} 34^{\prime} \mathrm{N}, 33^{\circ} 08^{\prime} \mathrm{E}$ ), general view of a small excavation at low tide, showing two specimens buried in mud (white arrows), detail of one specimen lying almost horizontally within the sediment, empty burrows a few centimeters below the water sediment interface (burrows underlined by white arrows). Abbreviations: at, annulated trunk; be, burrow entrance; po, tide pool; pr, proboscis; se, sediment; ta, tail ; wa, water; wo, worm; wsi, water-sediment interface. Scale bars: $10 \mathrm{~cm}$ in $\mathrm{g}, 1 \mathrm{~cm}$ in a-f, h, i.

Fig. 10. Skeletons and muscles in Cambrian scalidophoran worms, lobopodians and euarthropods. (a), (b) Trunk annulations in contracted and dilated state (through the action of longitudinal and circular cuticular muscle fibers) exemplified by Cricocosmia. (c) Assumed cuticular muscle fibers around the trunk of worms and lobopodians. (d) Simplified section through the trunk of Cricocosmia (partly buried in sediment). (e) Simplified morphology of a lobopodian leg, exemplified by Paucipodia (gray arrows indicate contact with substrate via a claw or the soft tip of leg). (f), (g) Lobopodian leg annulations in contracted and dilated state (presumably via the action of a retractor muscle). (h) Simplified longitudinal section through the flexible trunk of an arthropod showing articulated dorsal and ventral sclerotized sclerites. (i) Simplified diagram showing two jointed articles in an arthropod appendage; force is transmitted through rigid skeletal elements instead of internal pressure as in worms and lobopodians. Abbreviations: am, articular membrane; an, annulus; bc, body cavity; cc, coelomic cavity; cl, claw; cm; circular muscle fibers; co, condyle; cu, cuticle; dia, distal article; $\mathrm{ds}$, dorsal sclerite (tergite); em, extensor muscle; fm, flexor muscle; gu, gut; Im, longitudinal muscle fibers; pra, proximal article; rm, retractor muscle; sc, sclerite; scu, sclerotized cuticle; se, sediment; su, substrate; vs, ventral sclerite (sternite). Not to scale. $\mathrm{h}$ and $\mathrm{i}$ are simplified from Brusca and Brusca 2002, fig. 15-18B, C. 


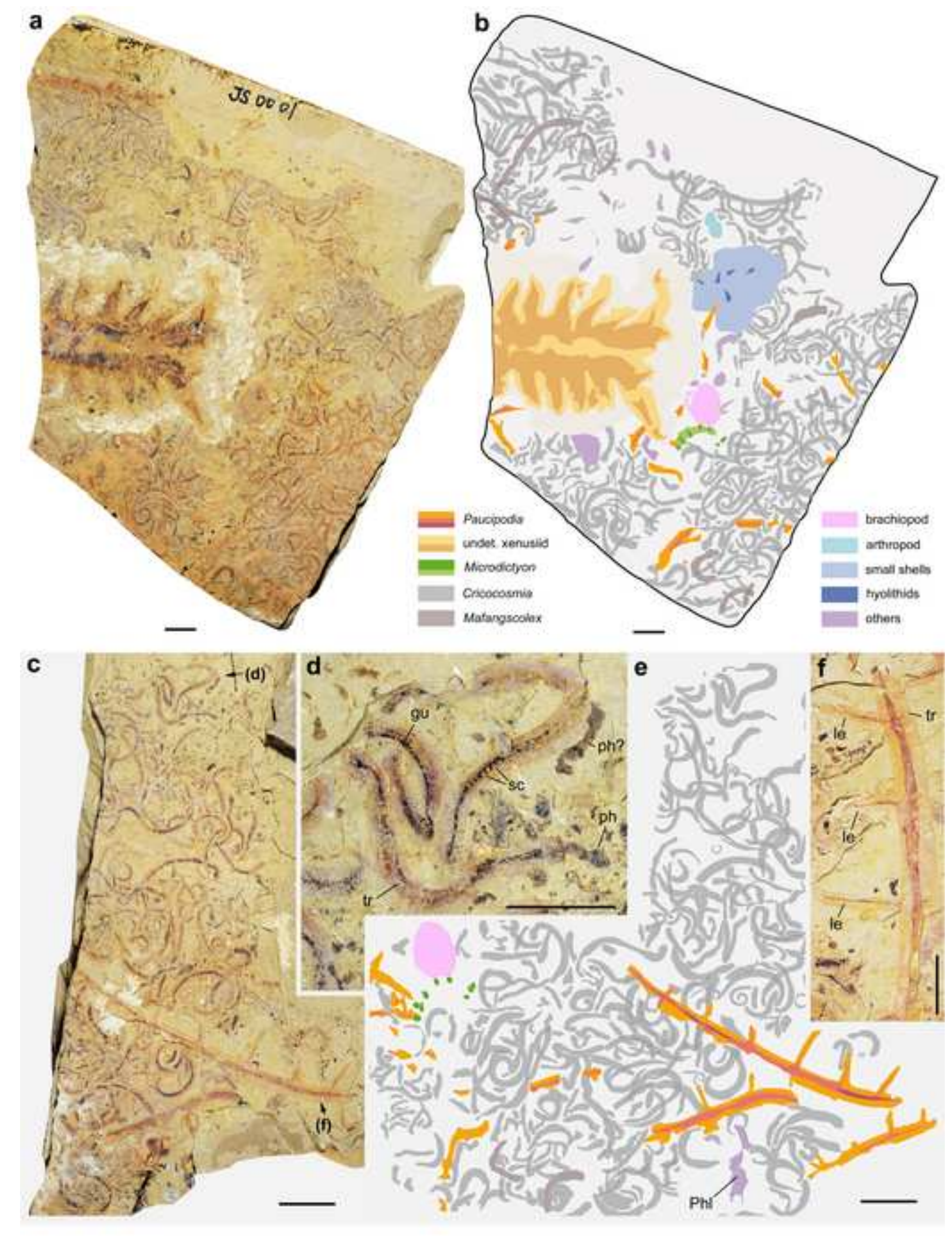




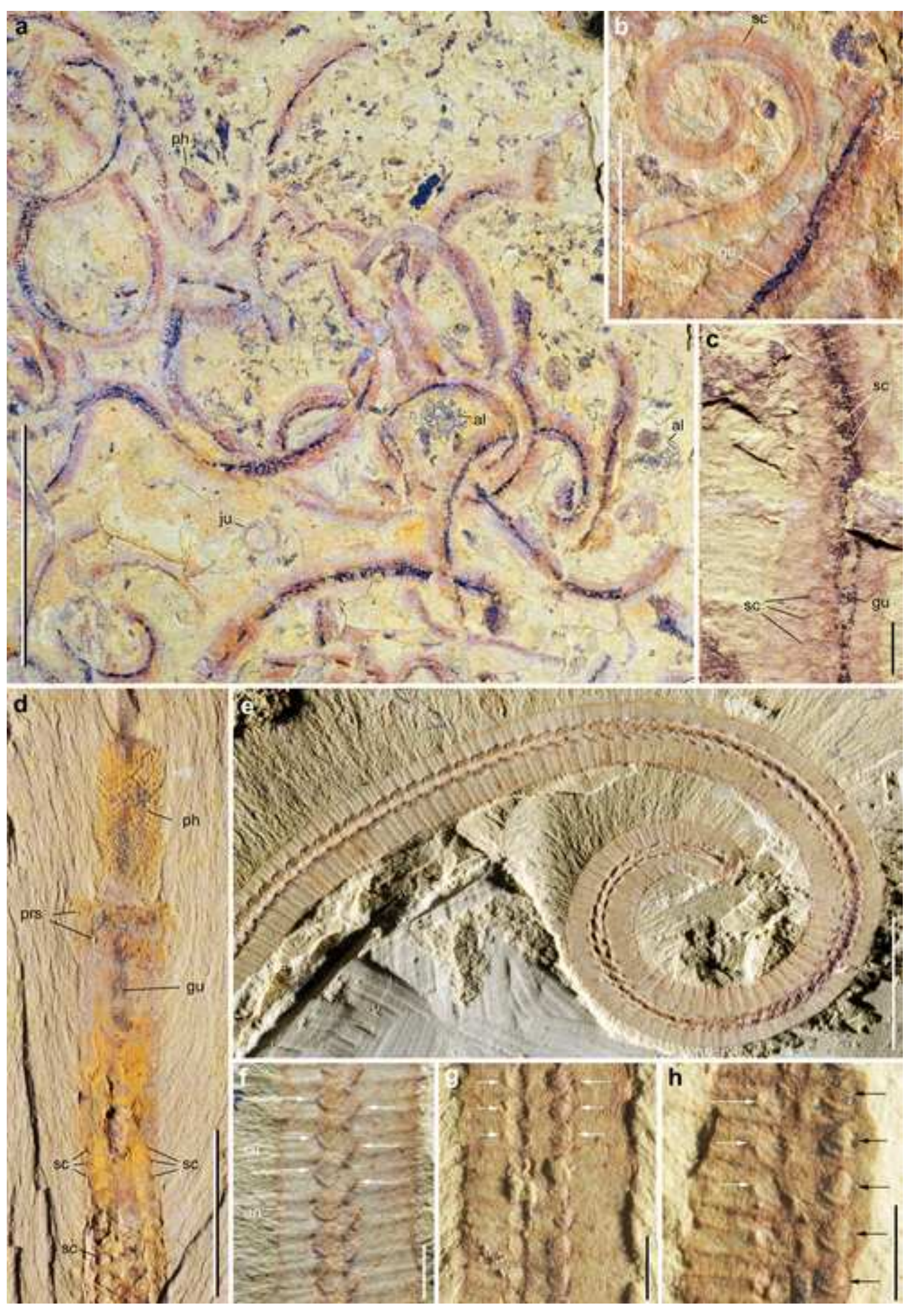




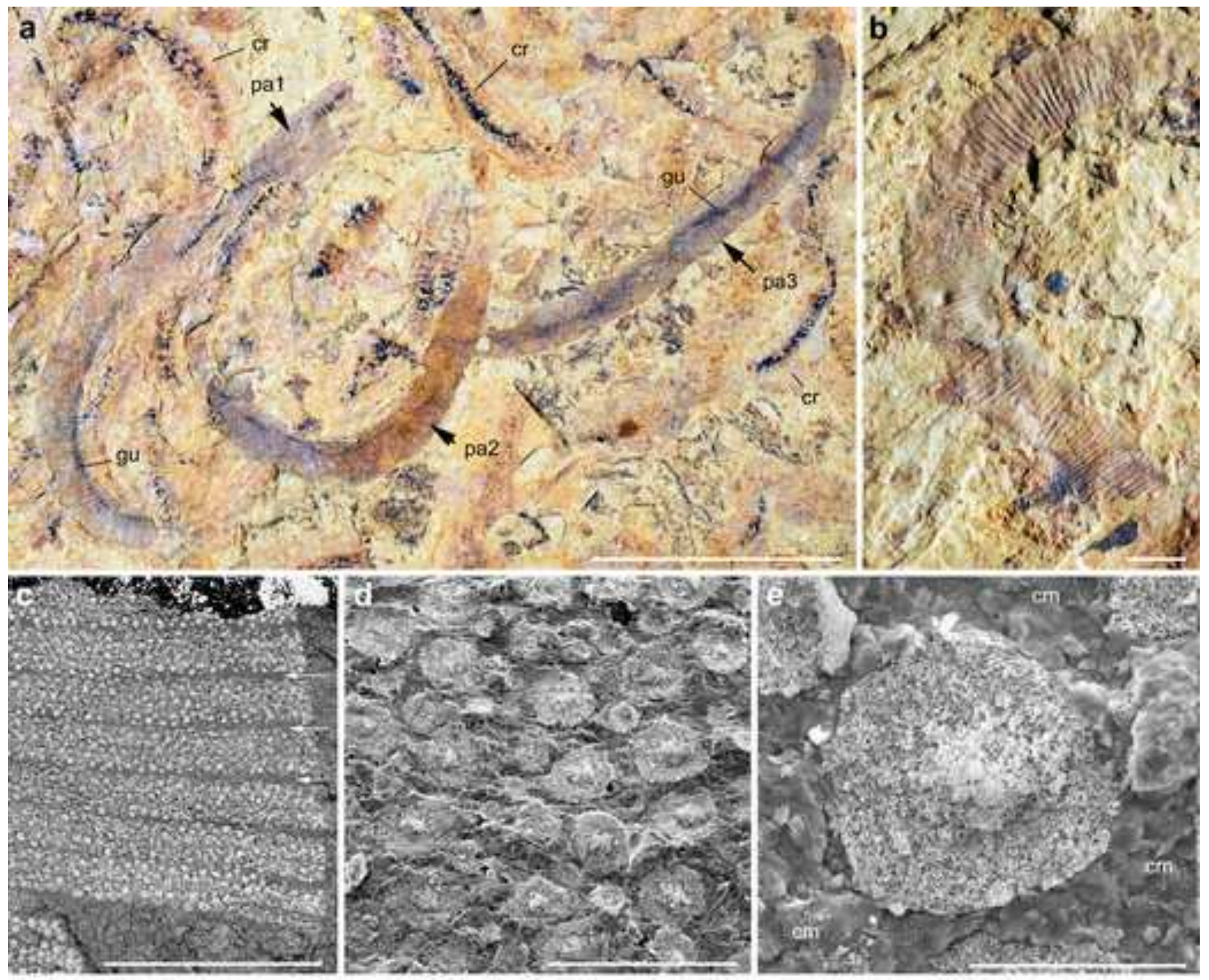




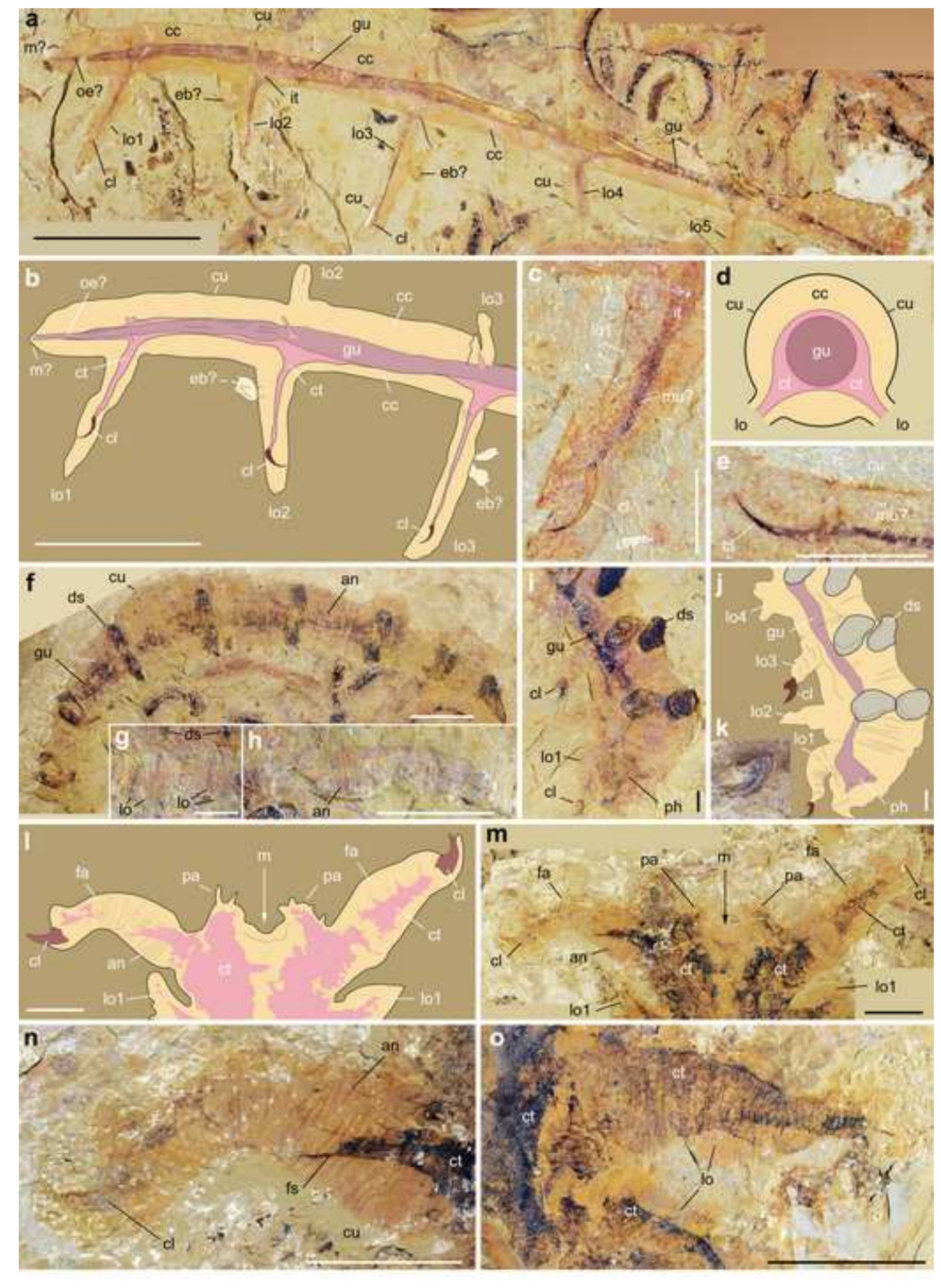

.
.

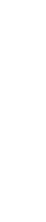

.

.




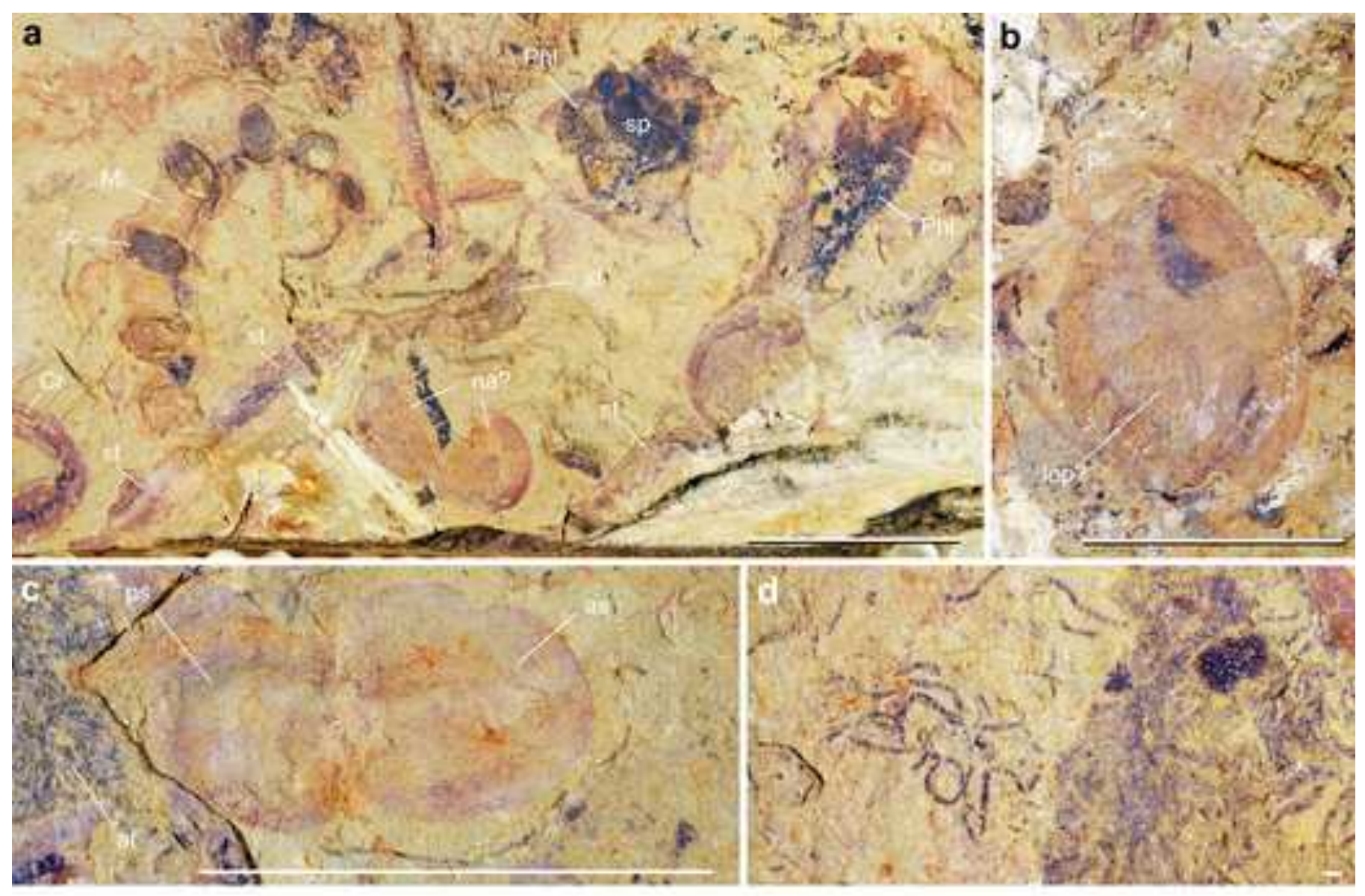

Figure

s

.
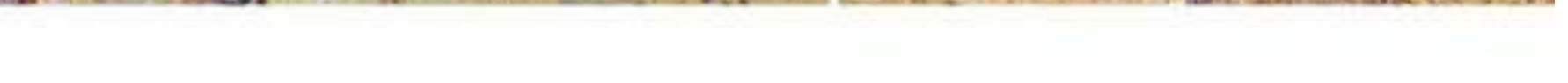

. 

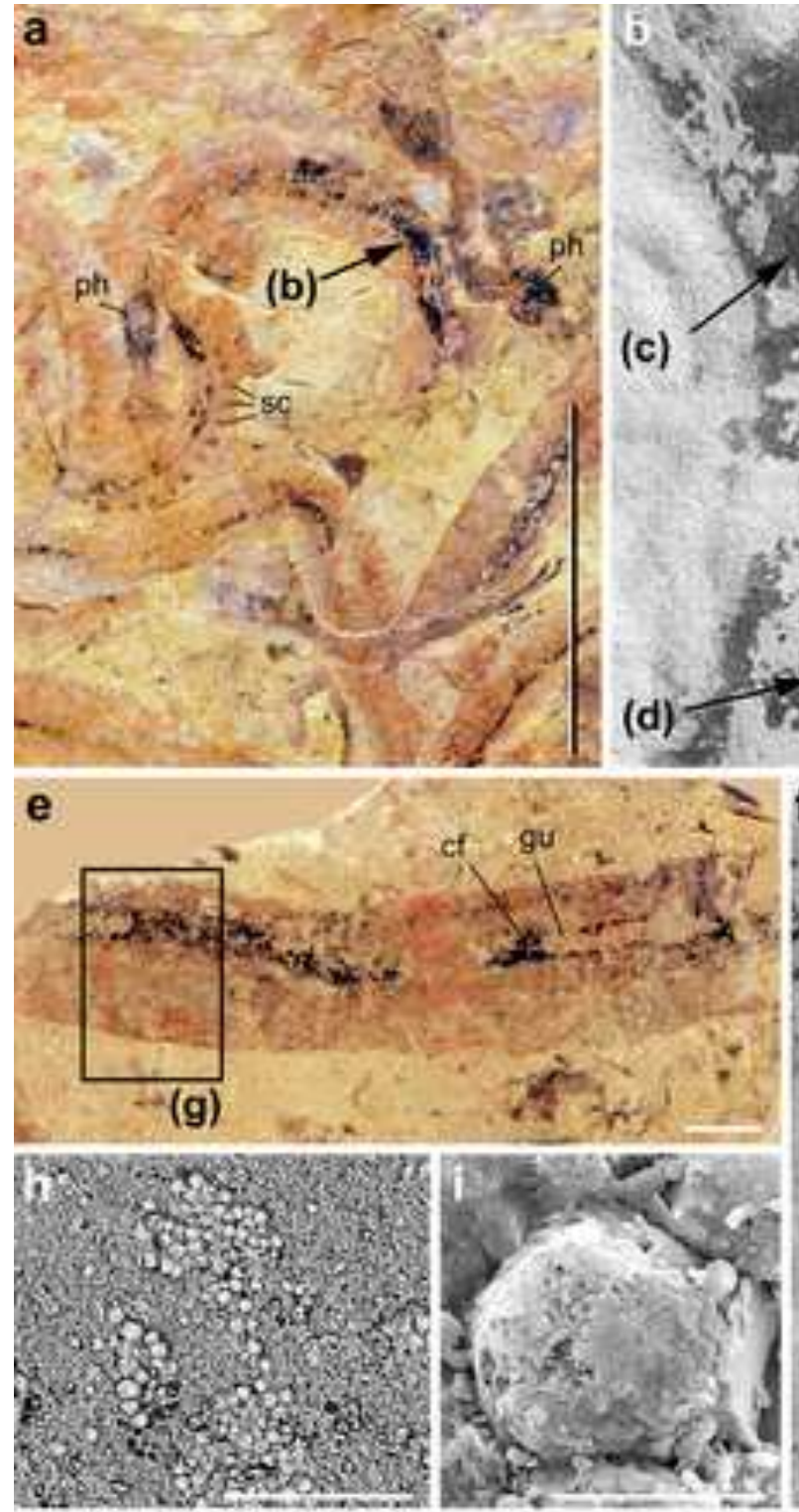

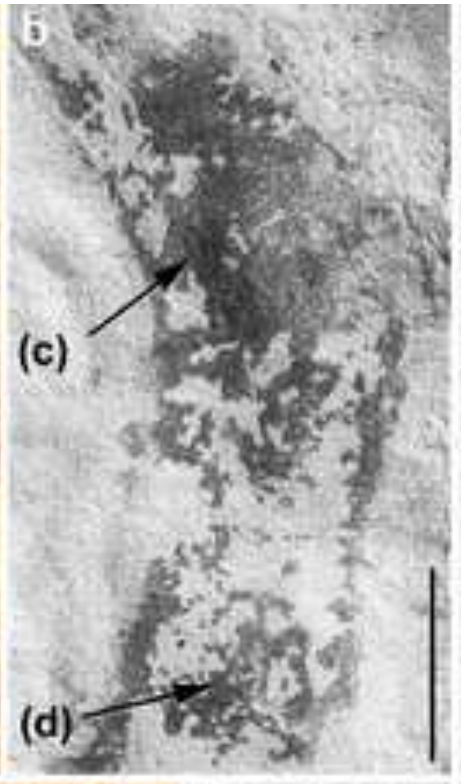

C

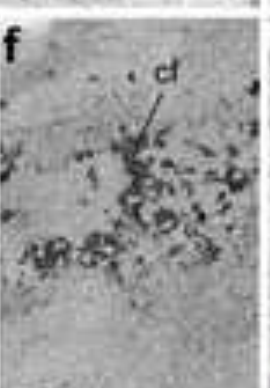

(h)
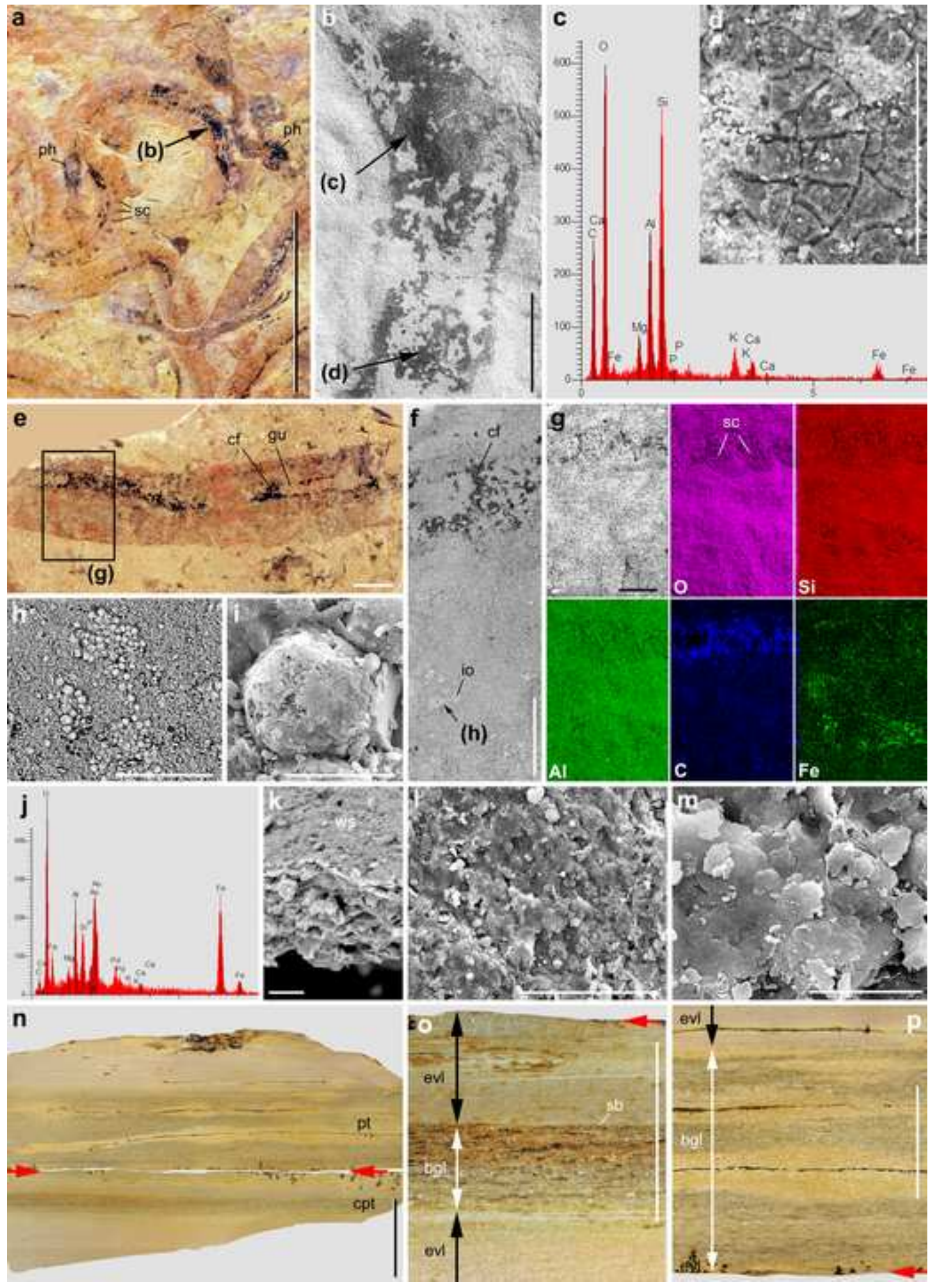

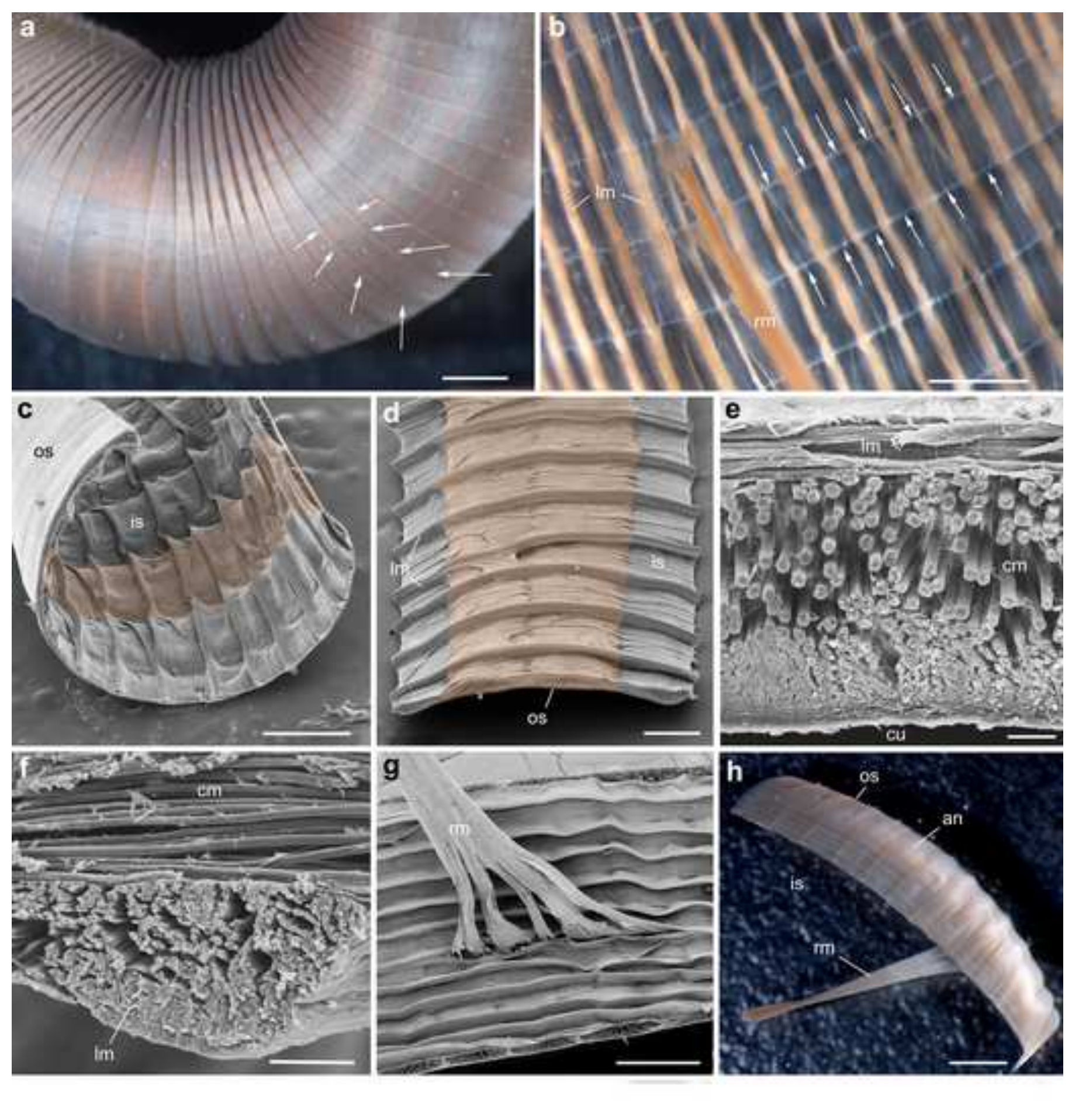

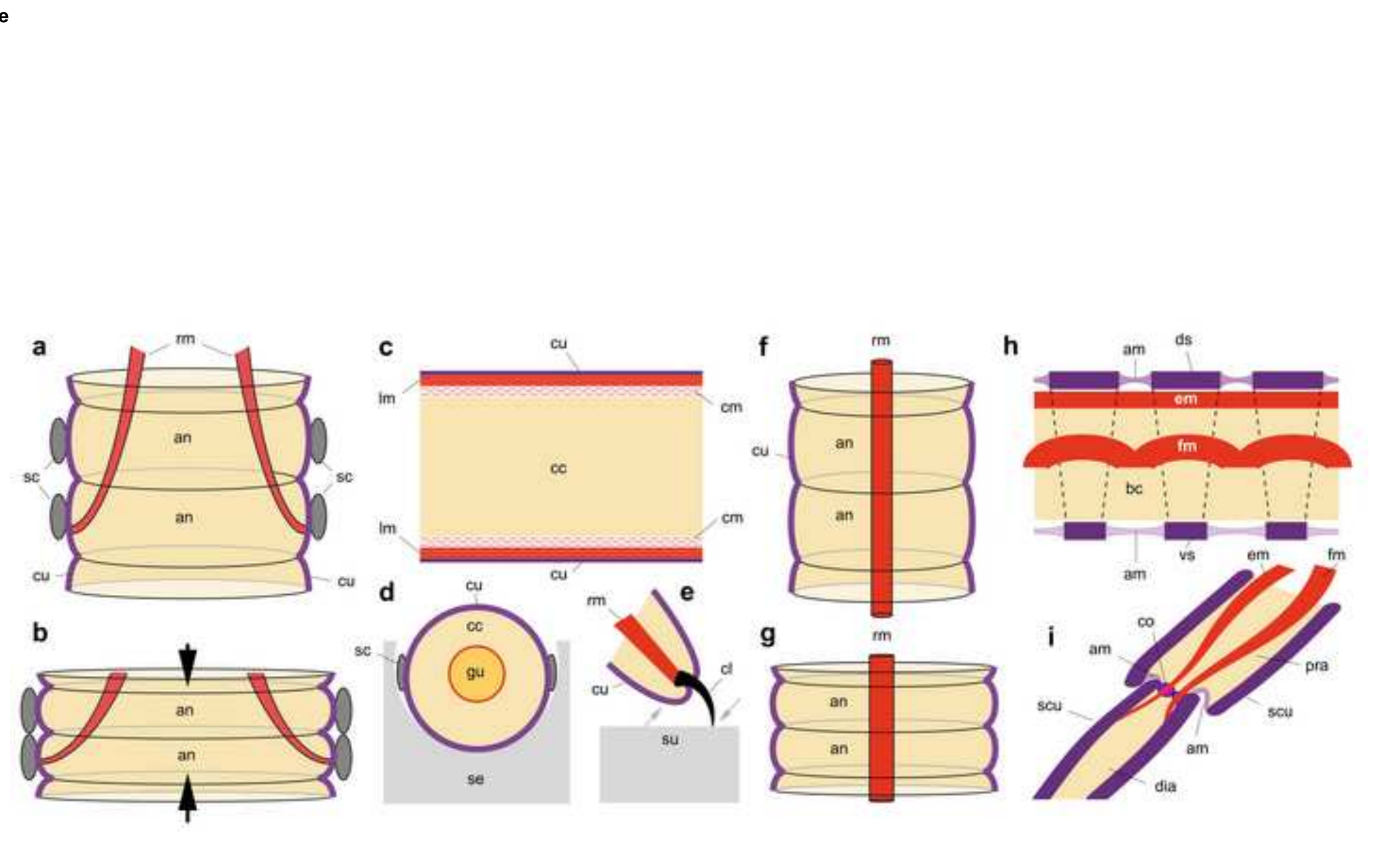

$$
\text { 政 }
$$

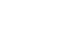

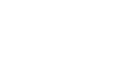

.

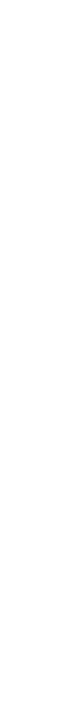

